\section{Dangerous dealings}

\section{Alex Comfort}

Contamination: A Novel. By Chapman Pincher. Sidgwick \& Jackson: 1989. Pp.343. £12.95.

DR Wendy Payne, a microbiologist reluctantly involved in an (unauthorized) British germ-warfare laboratory, whose "effulgence of sex ...through no conscious effort on her part, could cause stirrings in the private parts of men across the proverbial crowded room", has discovered a bacterial clone which can digest silicon - including that contained in heat-sealed microchips. She is very appropriately murdered on page 1 of this novel after licking an envelope laced with botulinus toxin. The CIA attempt to smuggle a potentially damaging supply of the bacteria in a Star Wars simulator consigned to the Soviet Union: although this is the period of glasnost and détente, hardfaced GRU plotters, treacherous opponents of the arms race, and contemptible Members belonging to the No Hope Party (the loyal Opposition?) who ask questions about MI5 operations, are all in evidence, and the plot is enacted by the licenced paranoiacs of three nations for 343 pages.

Chapman Pincher's style of writing and his conception of fiction remind me a little of the imitators of the late Nat Gould, but Nat Gould knew a great deal about racing and his backgrounds were plausible. The alarming feature of this extravaganza, which prevents it from being funny, is that Mr Pincher professes to know a lot about the inaptly named Intelligence Community, and his professions might be true. $\mathrm{He}$ pictures it as a battery of loose cannon, accountable to nobody, riddled with double and treble agents, capable of any excesses, however hare-brained, and sharing Mr Pincher's rather nutty political opinions. Could he possibly be right?

With the example of Spycatcher before them and $\mathrm{Mr}$ Pincher's confirmation, scientists might well conclude that intelligence is an ingredient conspicuously lacking from this bunch, and that to hand any interesting finding to such morons under conditions of secrecy is simply not tolerable. I doubt if the author intended it in that way, but this book, for any reader who doesn't give up in exasperation, is one further powerful argument for a Freedom of Information Act. It is easy to disbelieve that there really are people who think and act like this, but the Pincher analysis has confirmation from another 'inside' source several degrees of magnitude up the literary scale, in Le Carré's The Russia House.
Even if it were better written, one couldn't recommend this novel as light entertainment to any scientific reader least of all to any scientific reader who on patriotic or grant-obtaining grounds has inadvisedly committed him or herself to work of 'national importance'. If the Manhattan Project team lived to regret their trust in government, anyone under- taking similar work today, in peacetime, might well be moved by this insight into Pincherism to write two letters - one of resignation, the other, in a plain unpoisoned envelope, to $\mathrm{Mr}$ Tam Dalyell MP, blowing the whistle. He or she would probably be right.

Alex Comfort is at The Windmill House, The Hill, Cranbrook, Kent TN17 3AA, UK.

\section{In the fast lane}

\section{John Treherne}

Cantor's Dllemma. By Carl Djerassi. Doubleday, New York: 1989. Pp.231. $\$ 18.95$. To be published in Britain next Spring by Macdonald.

CARL Djerassi can write - there is no doubt about that - which is why reading his novel is such a bruising experience. The narrative bounces along from one repellent character to another. They really are a ghastly bunch.

Take Celestine, for example. At the beginning of the book she seems a relatively innocent little thing. Yet before leaving high school she has been deflowered by the swimming coach and has received her marching orders from the chemistry teacher: "the union card for serious research is a Ph.D. Get it as quickly as possible". To obtain a "top academic position", young Celestine is told - before she even sets foot in a university - that she must infiltrate the old boys' network by doing postdoctoral work "with two different mentors at two different institutions". If things turn out well she will then have three men in universities pushing for her. This is all very necessary, for, she is assured, "Chemistry is still a man's world".

Thus counselled, the poor girl takes off for a six-year "combined B.S.-Ph.D. program" at Johns Hopkins. There she works frenetically to further her career, both in the classroom and on her back - it still being a man's world in chemistry - with a dirty old man on the faculty, Professor Graham Lufkin, world expert on insect pheromones and an opera buff. But Celestine knows what she is about ("she felt the quality of intercourse with him - intellectual as well as sexual - was far superior to what her male peers could offer"). They are all like that on the fast track in Cantor's Dilemma. Very sportingly for such a cad (he also gives seminars with suggestive titles such as "One-night Stands Among Insects", much to the delight of his prurient audiences), Lufkin eventually sends her to do her $\mathrm{PhD}$ research with Jean Ardley. Ardley (formerly "Yardley"; she knocked off the "Y" to get alphabetical priority in multiauthor papers) is another fast-tracker who has had her "tubes tied up" and who, Celestine suspects, was previously bedded by the dreadful Lufkin.

Celestine is next laid by Jeremiah (Jerry) Stafford, of whom she becomes quite fond (despite the fact that he at first lacks "the deft touch of Lufkin"). He is the research student of Professor I.C. Cantor, a big-shot molecular biologist with bushy hair, a large nose and very highly developed ambitions - which include winning the Nobel prize specifically by formulating a

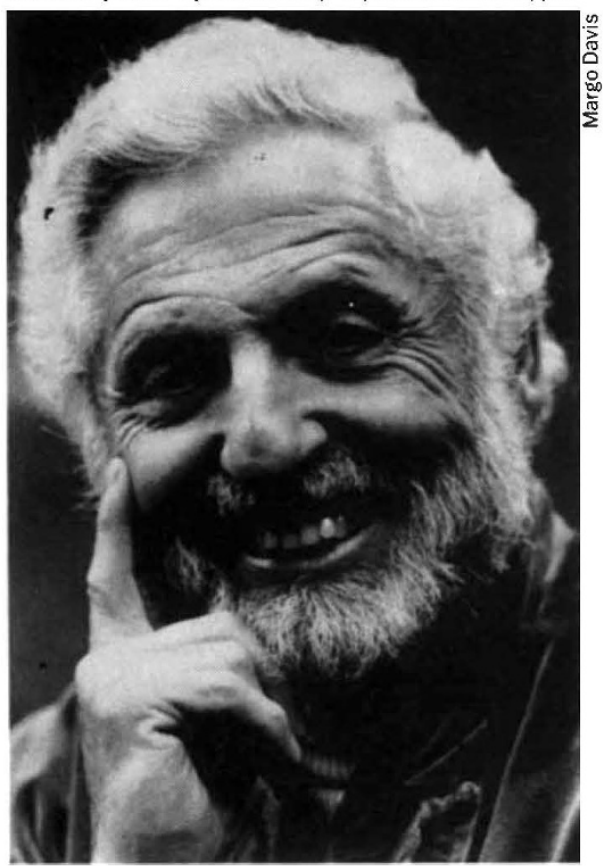

Djerassi — telling a tale

new theory of tumorigenesis. As Professor Djerassi puts it: "In the cancer field. . . a generalized theory of tumor production is Mount Everest or K-2. Only superstars climb such peaks, and even they use Sherpas. I. Cantor was such a superstar and Stafford became his Sherpa". - for a scientist at least - with his Patek Philippe watch, BMW sedan, silk necktie (worn even in the laboratory), gold Mont Blanc fountain pen, his valuable collection of erotic paintings and expert playing in a Boccherini quintet. Like everyone else in the book he is without a vestige of humour. It is in the quintet that he meets Celestine's Auntie Paula (who is pretty fancy herself - not only does she have expensive antiques and play the cello, but she makes some really helpful remarks about cunnilingus when I.C. shows her his
The superstar turns out to be a real dude 